\title{
Hiilirisasi Daya Saing Dan Potensi Pengembangan Pasar Produk Karet Indonesia di Negara Asean5
}

\author{
Zainuddin \\ Program Studi Agribisnis Fakultas Pertanian Universitas Batanghari \\ J1. Slamet Riyadi-Broni, Jambi. 36122. Tel. +6274160103 \\ e-mail : zainuddin.ubr11@gmail.com
}

\begin{abstract}
The increase in exports of Indonesian rubber products is the key to the success of the rubber product downstream policy to gain added value and foreign exchange. The export market for rubber products in ASEAN5 is competing with similar products from East Asia. As an exporter, Indonesia must focus on strengthening competitiveness and exploiting the potential market in ASEAN5.The purpose of this article is to describe the competitiveness and development potential of the Indonesian rubber product market in ASEAN5 countries (Singapore, Malaysia, Thailand, Vietnam, the Philippines). The analysis that describes the competitiveness of Indonesian rubber products uses the RCA method and market share. Analysis of the position and potential for market development of Indonesian rubber products using the Export Product Dynamic method. The competitiveness of Indonesian rubber products in ASEAN5 markets is quite varied. Indonesian rubber products have a relatively strong competitiveness value in the Singapore market, but weak in other ASEAN5 markets such as Malaysia, Thailand, the Philippines and Vietnam. Indonesian rubber products compete fiercely with similar industries in importing countries and major competitors from East Asia (China, Japan, South Korea). The clusterization shows that Indonesian rubber products have a potential market in Thailand, although their competitiveness is relatively weak but in a rising star market position. The market potential in Singapore and the Philippines is less potential, but has relatively strong competitiveness in Singapore and a falling star market position in the Philippines. Indonesian rubber products have no potential in Malaysia and Vietnam.
\end{abstract}

Keywords: rubber products, competitiveness, potential for market development

\begin{abstract}
Abstrak. Peningkatan ekspor produk karet Indonesia adalah kunci sukses kebijakan hilirisasi produk perkebunan karet untuk meraih nilai tambah dan devisa. Pasar ekspor produk karet di ASEAN5 bersaing ketat dengan produk sejenis dari Asia Timur. Sebagai pengekspor, Indonesia harus fokus memperkuat daya saing dan memanfaatkan market potential di ASEAN5. Tujuan penulisan artikel ini adalah menggambarkan daya saing dan potensi pengembangan pasar produk karet Indonesia di negara ASEAN5 (Singapore, Malaysia, Thailand, Vietnam, Filipina). Analisis yang menggambarkan daya saing produk karet Indonesia menggunakan metode RCA dan market share. Analisis posisi dan potensi pengembangan pasar produk karet Indonesia menggunakan metode Export Product Dynamic. Daya saing produk karet Indonesia di pasar negara ASEAN5 cukup bervariasi. Produk karet Indonesia memiliki nilai daya saing relatif kuat di pasar Singapore, namun lemah pada pasar negara ASEAN5 lainnya seperti Malaysia, Thailand, Filipina dan Vietnam. Produk karet Indonesia bersaing ketat dengan industri sejenis di negara pengimpor dan pesaing besar dari Asia Timur (Cina, Jepang, Korea Selatan). Klasterisasi menunjukkan produk karet Indonesia memiliki pasar potensial di Thailand, walaupun daya saing relatif lemah tetapi pada posisi pasar rising star. Potensi pasar di Singapore dan Filipina pada posisi kurang potensial, namun memiliki daya saing di Singapore relatif kuat dan posisi pasar falling star di Filipina. Produk karet Indonesia tidak potensial di Malaysia dan Vietnam.
\end{abstract}

Kata kunci: produk karet, daya saing, potensi pengembangan pasar

\section{PENDAHULUAN}

Indonesia adalah negara dengan sumberdaya alam relatif besar sehingga memungkinkan menghasilkan banyak komoditas dengan kelimpahan sumberdaya alam tersebut. Karet alam telah menjadi komoditas penting dalam industri dan perdagangan Indonesia. Disamping komoditas primer, Indonesia juga telah mengembangkan produk olahan karet untuk pasar domestik dan ekspor. Manfaat ekonomi penting dari industri olahan produk karet domestik adalah meningkatkan serapan karet alam petani, menciptakan nilai tambah, mendorong ekspor produk olahan, meningkatkan perolehan devisa, menciptakan kesempatan kerja, dan mendorong pembangunan daerah. Sebagai bahan baku industri pengolahan, karet alam dianggap unik karena memiliki sifat elasticity, toughness and resilience yang menjadikannya sebagai aspek komersial penting produk industri pengolahan karet. Industri produk karet Indonesia secara perlahan didorong oleh ekspor dan permintaan domestik. Indonesia mengekspor produk karet khususnya kode HS 4008, 4009, 4010, 4014, 4015, 4016 ke berbagai negara mencapai rata-rata 374 juta dollar pada periode 2001 sampai 2018. Ekspor produk karet tersebut ke negara-negara ASEAN mencapai 61.19 juta dollar atau pangsa sebesar 16.99 persen (UN Comtrade, 2020).

Singapore adalah negara tujuan ekspor produk karet Indonesia terbesar dengan pangsa 50.73 persen pada periode 2001 sampai 2018. Kemudian diikuti Thailand 16.07 persen, Malaysia 13.41 persen, Vietnam 10.24 persen dan Filipina 5.55 persen (UN Comtrade, 2020). Jenis produk karet yang diminta pasar Singapore relatif lengkap mulai kelompok produk kode HS4008, 4009, 4010, 4014, 4015 sampai 4016. Pasar ekspor relatif kecil untuk produk karet Indonesia kode HS4014 dan 4015 di Thailand dan Filipina. Pasar ekspor produk karet Indonesia dengan kode HS 4014 juga relatif kecil di Malaysia dan Vietnam. 
Produk olahan lain dari karet adalah produk pakaian dan aksesori pakaian dari karet divulkanisasi, sarung tangan (gloves, mittens and mitts) dengan code HS 4015. Indonesia mengekspor relatif besar untuk jenis produk karet dengan kode HS 4016 berupa karet selular (rubber cellular), penutup lantai dan tikar karet (floor coverings and mats), penghapus karet (erasers), gasket dan ring komponen mesin (gaskets and ring), sandaran kapal dan dermaga (boats and dermaga fender).

Isu penting pengembangan industri dan ekspor karet Indonesia adalah lambatnya hilirisasi produk olahan karet alam, sehingga komponen ekspor lebih dominan dari karet alam sebagai bahan baku (TSNR, RSS, Latex) dibandingkan produk karet. Indonesia melakukan ekspor relatif besar berbagai jenis produk karet. Selama lebih dari dua dekade mengembangkan industri produk karet, negara produsen karet alam termasuk Indonesia hanya menempati ranking 6 sampai 12 negara eksportir terbesar produk karet, sedangkan ranking 1 sampai 5 ditempati oleh Cina, Jepang, Amerika Serikat, Jerman, dan Korea Selatan. Produk karet Indonesia dan begitu juga Malaysia dan Thailand bersaing dengan industri negara besar pengekspor produk karet lainnya di pasar dunia (Zainuddin, 2019; Zainuddin, et.al, 2019).

Masa depan keemasan ekspor karet alam mentah semakin tidak menguntungkan mengacu kepada Blagrave dan Vesperoni (2016), Dinda (2017), Oktora dan Firdani (2019), Sattayawaksakul dan Seung (2016), Basri, et.al (2018) dan Ramli, et.al (2019). Untuk mempercepat hilirisasi produk karet perlu didukung dengan peningkatan permintaan terutama dari pasar ekspor. Salah satu upaya untuk meningkatkan ekspor produk karet Indonesia ke pasar dunia adalah dengan penetrasi pasar. Penetrasi produk karet di suatu pasar ekspor memerlukan informasi potensi dan posisi pasar atas dasar daya saing produk dalam suatu pemetaan potensi permintaan impor produk karet. Informasi mengenai daya saing dan posisi pasar akan menentukan potensi pengembangan pasar produk karet di negara tujuan ekspor.

Gambaran daya saing dan potensi pengembangan pasar produk karet Indonesia di negara tujuan ekspor memberikan informasi dan masukan penting dalam perumusan kebijakan peningkatan dan pengembangan ekspor produk karet Indonesia khususnya ke negara di kawasan ASEAN5. Tujuan penelitian ini adalah menggambarkan hilirisasi, daya saing dan potensi pengembangan pasar produk karet Indonesia (kode HS 4008, 4009, 4010, 4014, 4015 dan 4016) di negara-negara ASEAN5 khususnya Malaysia, Singapore, Thailand, Filipina dan Vietnam.

\section{METODOLOGI PENELITIAN}

Penelitian ini fokus pada daya saing dan potensi pengembangan pasar ekspor produk karet Indonesia ke berbagai negara di ASEAN5. Jenis produk karet adalah produk olahan karet alam dengan kode HS 4008, 4009, 4010, 4014, 4015, 4016. Jenis data yang digunakan adalah times series dalam rentang tahun 2009 sampai 2018. Data berupa ekspor produk karet Indonesia ke negara tujuan ekspor di ASEAN5, ekspor produk karet seluruh negara di dunia ke negara tujuan ekspor di ASEAN5, total ekspor seluruh produk Indonesia ke negara tujuan ekspor di ASEAN5, dan total ekspor seluruh produk dari seluruh negara di dunia ke negara tujuan ekspor di ASEAN5, semuanya bersumber dari komisi perdagangan United Nations (UN Comtrade). Ekspor produk karet Indonesia dan negara lainnya berdasarkan kode HS (Harmonize System) diukur dalam bentuk nilai (USDjuta) tiap tahun dan merupakan total dari semua jenis produk karet.

\section{Revealed Comparative Advantage (RCA)}

Pada awalnya metode Revealed Comparative Advantage (RCA) dikenalkan oleh Balassa (1965 dan 1989) yang mengukur keunggulan komparatif dalam perdagangan internasional melalui nisbah atau rasio ekspor impor. Namun pengukuran dengan rasio ekspor impor memiliki berbagai kelemahan seperti campur tangan pemerintah dan berbagai distorsi pasar sehingga menimbulkan bias pengukuran keunggulan komparatif suatu komoditas atau produk. Balassa melakukan perbaikan dengan memodifikasi perumusan dengan menggunakan relative export share. Pangsa ekspor relatif digunakan karena data impor cenderung lebih bias dibandingkan data ekspor karena pemerintah memberlakukan berbagai pengaturan untuk menekan impor (Basri dan Munandar 2010). Penghitungan RCA ini dapat mengidentifikasi apakah suatu komoditas eskpor sebuah negara memiliki keuntungan komparatif atau tidak. Kelemahan analisis ini adalah bersifat statis dan adanya asumsi bahwa setiap negara mengekspor semua komoditas atau kelompok komoditas yang diteliti.

Keunggulan komparatif suatu negara direfleksikan oleh ekspornya. Suatu negara memiliki keunggulan komparatif dalam memproduksi suatu barang bila biaya pengorbanannya dalam memproduksi barang tersebut lebih rendah daripada negara-negara lainnya (Krugman \& Obstfeld 2003). Metode RCA digunakan untuk mengukur kinerja ekspor komoditas tertentu dari suatu negara dengan mengevaluasi peranan ekspor komoditas tersebut di dalam ekspor total suatu negara dibandingkan dengan pangsa komoditas tersebut dalam perdagangan dunia (Basri dan Munandar,2010). Konsep RCA dikatakan sebagai perdagangan antar wilayah sebenarnya menunjukkan

keunggulan komparatif yang dimiliki oleh suatu wilayah. Variabel yang diukur adalah kinerja ekspor suatu produk terhadap total ekspor suatu wilayah yang kemudian dibandingkan dengan pangsa nilai produk dalam perdagangan 
dunia (Tarman et al. 2011). Melalui pengukuran dengan metode RCA ini, akan diketahui keunggulan komparatif suatu negara. Keunggulan komparatif tersebut merupakan daya saing suatu komoditas ekspor dari suatu negara terhadap ekspor komoditas tersebut di seluruh dunia.

Variabel yang diukur dalam penelitian ini adalah kinerja ekspor berbagai produk karet Indonesia ke negaranegara ASEAN5 (Malaysia, Singapore, Thailand, Filipina, Vietnam) dengan menghitung pangsa nilai ekspor terhadap total ekspor ke negara tujuan ekspor yang kemudian dibandingkan dengan pangsa nilai ekspor dunia ke negara negara tujuan ekspor tersebut. Dalam bentuk matematis, indeks RCA untuk produk karet Indonesia yang diekspor ke negara-negara ASEAN5 dapat dituliskan:

$$
R C A^{i j}=\frac{X^{r i}}{X^{i}} / \frac{X^{r w}}{X^{w}}
$$

dimana

$X^{r i}$ : Nilai ekspor produk karet dari Indonesia ke negara tujuan ekspor di ASEAN5

$X^{i} \quad$ : Nilai total ekspor dari Indonesia ke negara tujuan ekspor di ASEAN5

$X^{r w}$ : Nilai ekspor produk karet dunia ke negara tujuan ekspor di ASEAN5

$X^{w} \quad$ : Nilai total ekspor dunia ke negara tujuan ekspor di ASEAN5

$i$ adalah Indonesia dan $j$ adalah negara tujuan ekspor di ASEAN5

Jika nilai indeks RCA suatu negara untuk suatu produk karet lebih besar dari satu (RCA > 1), maka negara bersangkutan memiliki keunggulan komparatif di atas rata-rata dunia untuk produk karet tersebut. Sebaliknya, bila lebih kecil dari satu $(\mathrm{RCA}<1)$, keunggulan komparatif suatu negara untuk produk karet tersebut dinilai rendah atau lemah. Semakin besar nilai indeks RCA, semakin tinggi pula tingkat keunggulan komparatif produk karet tersebut.

\section{Export Product Dynamic (EPD)}

Metode ini digunakan untuk menentukan keunggulan kompetitif komoditas tertentu dari suatu negara. Export Product Dynamic (EPD) juga dapat menentukan gerakan dinamis suatu komoditas, yaitu apakah daya saing suatu produk mempunyai performa yang dinamis (memiliki pertumbuhan cepat) atau tidak, dengan kata lain melihat posisi daya saing produk terhadap negara importir terbesar. Jika pertumbuhan komoditas itu berada di atas rata-rata dunia dan keadaan ini berlanjut dalam jangka panjang, komoditas ini akhirnya dapat menjadi sumber penting pendapatan ekspor suatu negara. Menurut Esterhuizen (2006), keberhasilan di pasar ekspor perlu diinterpretasikan dengan hatihati. Hilangnya beberapa pangsa pasar dalam perdagangan tidak selalu berarti hilangnya daya saing secara keseluruhan, yaitu apabila ada peningkatan pangsa pada produk lain.

Produk industri suatu negara dianggap kompetitif apabila pangsa pasar mereka terus meningkat, dan dianggap dinamis dalam perdagangan dunia jika pangsa pasarnya tumbuh lebih cepat daripada rata-rata pertumbuhan semua produk. Dalam metode Export Product Dynamic, posisi pasar yang ideal adalah memiliki pangsa ekspor yang tinggi sebagai rising stars yang mengindikasikan bahwa produk negara tersebut memiliki pangsa pasar yang tumbuh cepat. Sedangkan posisi lost opportunity, merupakan posisi hilangnya pangsa pasar dari produk yang sebetulnya dinamis. Posisi ini merupakan posisi yang paling tidak diinginkan. Falling stars juga merupakan posisi yang tidak diinginkan, sebab dalam posisi ini berada dalam kondisi dimana pangsa pasar meningkat, namun produk tidak dinamis. Posisi ini lebih baik bila dibandingkan dengan posisi lost opportunity, sedangkan posisi retreat merupakan posisi yang juga tidak diinginkan yang ditandai dengan pangsa pasar hilang dan produk tidak dinamis.

Sebuah matriks EPD terdiri dari daya tarik pasar dan informasi kekuatan bisnis. Daya tarik pasar dihitung berdasarkan pertumbuhan dari permintaan sebuah produk untuk tujuan pasar tertentu, sedangkan informasi kekuatan bisnis diukur berdasarkan pertumbuhan dari perolehan pasar (market share) sebuah negara pada tujuan pasar tertentu. Kombinasi dari daya tarik pasar dan kekuatan bisnis ini menghasilkan karakter posisi dari produk yang ingin dianalisis ke dalam empat kategori. Keempat kategori itu adalah rising star, falling star, lost opppotunity, dan retreat. Matriks posisi daya saing untuk melihat ekspor produk karet Indonesia ke negara tujuan ekspor di ASEAN5 pada penelitian ini dapat dilihat pada Tabel 1 .

\section{Tabel 1. Matriks Posisi Daya Saing}

\begin{tabular}{lcc}
\hline \multicolumn{1}{c}{ Share of Country's Export in ASEAN Country } & \multicolumn{2}{c}{ Share of Product in ASEAN Country Trade } \\
\cline { 2 - 3 } Trade & Rising (Dynamic) & Falling (Stagnant) \\
\hline Rising (Competitive) & Rising Star & Falling Star \\
Falling (Non-Competitive) & Lost Opportunity & Retreat \\
\hline
\end{tabular}

Sumber: Adaptasi dari Esterhuizen, 2006 
Tabel 1 diatas dapat dikonversikan sebagaimana Gambar 1 sebagai suatu matrik untuk menyederhanakan dalam memetakan posisi daya saing produk karet di masing-masing negara tujuan ekspor di ASEAN5. Produk diduga menempati salah satu dari empat kuadran tergantung dari daya tarik pasar dan kekuatan bisnis produk karet Indonesia. Menurut Hasibuan, et al. (2012), dalam matrik tersebut yang dimaksud dengan pangsa pasar ekspor suatu negara dan pangsa produk dalam perdagangan internasional tercermin dalam rumus perhitungan sumbu $\mathrm{X}$ dan sumbu Y. Pada Gambar 1, sumbu X menggambarkan pertumbuhan pangsa nilai pasar ekspor produk karet Indonesia ke negara tujuan ekspor di ASEAN5 dibandingkan dengan nilai pasar ekspor produk karet dari dunia ke negara tujuan ekspor di ASEAN5. Secara matematis dapat dituliskan:

Sumbu $X=\frac{\sum_{t=1}^{t}\left(\frac{X^{r i}}{X^{r w}}\right)_{t} x 100 \%-\sum_{t=1}^{t}\left(\frac{X^{r i}}{X^{r w}}\right)_{t-1} x 100 \%}{T}$

Sedangkan sumbu Y menggambarkan pertumbuhan pangsa pasar nilai total ekspor produk dalam perdagangan Indonesia ke negara tujuan ekspor di ASEAN5 dibandingkan nilai pasar total ekspor produk dari dunia ke negara tujuan ekspor di ASEAN5. Secara matematis dapat dituliskan :

Sumbu $\mathrm{Y}=\frac{\sum_{t=1}^{t}\left(\frac{X^{i}}{X^{w}}\right)_{t} x 100 \%-\sum_{t=1}^{t}\left(\frac{X^{i}}{X^{w}}\right)_{t-1} x 100 \%}{T}$

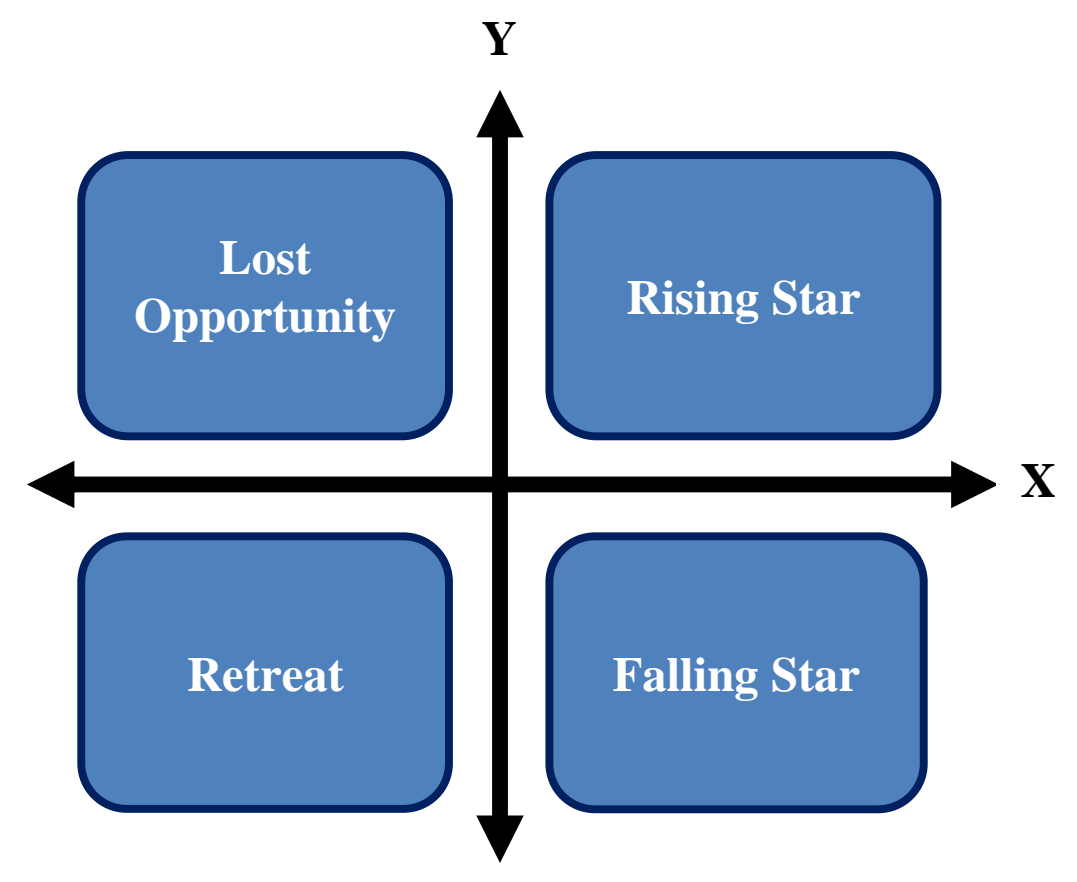

Sumber: Esterhuizen, 2006

Gambar 1. Posisi daya saing produk dengan metode Export Product Dynamics

Dimana T merupakan jumlah periode tahun analisis, $\mathrm{t}$ menunjukkan tahun ke-t. Posisi pasar ideal adalah yang mempunyai pangsa pasar yang tinggi ekspor produk karet maupun total produk sebagai rising star yang menunjukkan bahwa negara tersebut memperoleh tambahan pangsa pasar yang tumbuh cepat (fast-growing products). Lost opportunity terkait dengan kehilangan kesempatan karena terjadi penurunan pangsa pasar pada produk karet yang dinamis pada saat produk produk ekspor lainnya meningkat pangsanya dan kondisi ini tidak diinginkan. Falling star merupakan posisi yang tidak disukai, namun lebih baik jika dibandingkan dengan posisi lost opportunity karena pangsa pasar ekspor produk karet tetap meningkat. Kuadran yang menunjukkan posisi retreat atau "kemunduran" juga tidak diinginkan, tetapi pada kasus tertentu mungkin diinginkan jika pergerakannya menjauhi produk-produk yang stagnan dan menuju produk-produk yang dinamik (Esterhuizen, 2006).

\section{X-Model Potential Export Products (X-Model)}

$X$-Model Potential Export Products merupakan metode yang menggabungkan antara metode Revalead Comparative Advantage (RCA) dan metode Export Product Dynamics (EPD). Metode ini digunakan untuk melakukan klusterisasi produk yang memiliki potensi pengembangan tinggi atau rendah di wilayah tertentu. 
Klusterisasi ini dilakukan untuk memfokuskan pasar perdagangan. Dengan metode ini dapat disimpulkan apakah komoditas yang dianalisis memiliki potensi yang tinggi atau tidak di negara tujuan ekspor. Gambar 2 menunjukkan klusterisasi Analisis X-Model Potential Export Products:

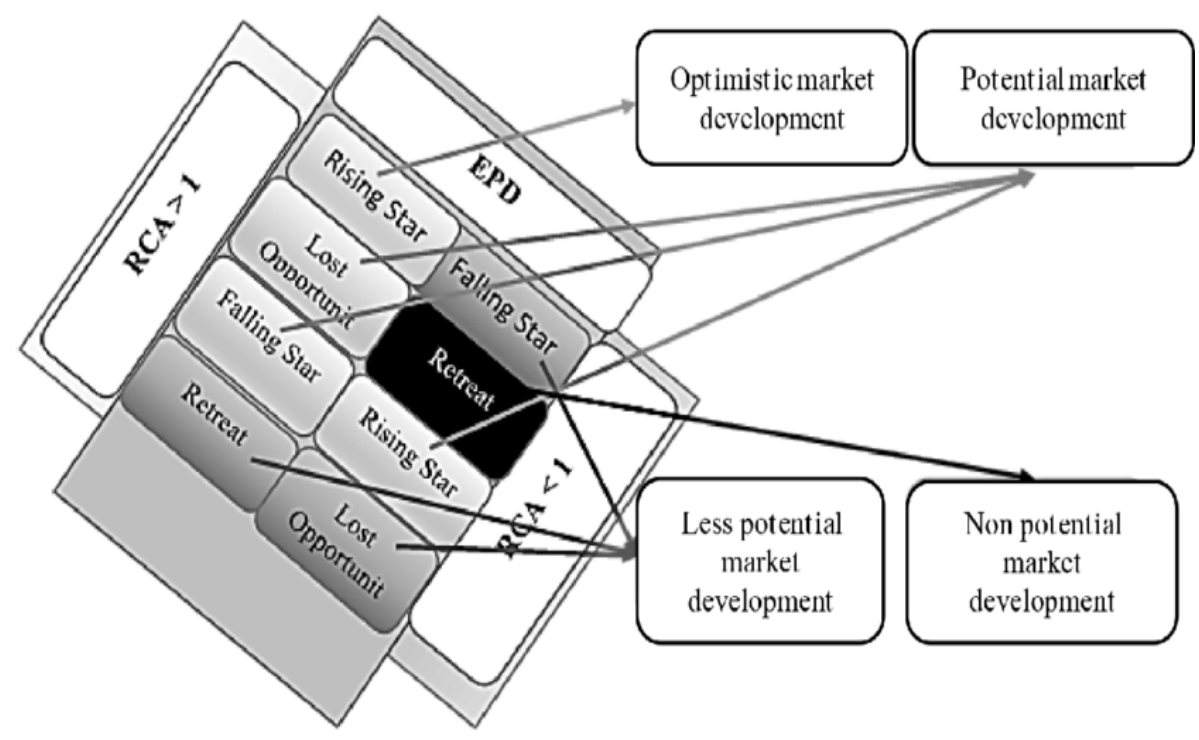

Sumber: Kemendag, 2013

Gambar 2. Analisis X-Model Potential Export Products

\section{Hilirisasi dan Ekspor Produk Karet}

\section{HASIL PENELITIAN}

Industri karet merupakan salah satu industri yang diprioritaskan pada rencana induk pengembangan industri nasional (RIPIN) dan rencana pengembangan jangka menengah industri nasional (RPJMN). Indonesia merupakan salah satu negara utama penghasil karet alam (produksi lebih dari 3 juta ton per tahun). Ekspor produk hasil hilirisasi industri karet domestik mencapai sebesar USD 2.1 miliar pada tahun 2016 (surplus sebesar USD 1.07 miliar) atau mencapai 37 persen dari total ekspor karet alam dan barang/produk karet secara keseluruhan yang mencapai USD 5.66 miliar. Dilihat dari sisi volume sekitar 80 persen karet alam Indonesia diekspor sebagai bahan baku (TSR, RSS, latex, brown crepe, dan lainnya) sehingga pertumbuhan ekspor sangat berpengaruh terhadap volatilitas harga komoditi karet alam.

Industri karet dan barang/produk karet dikelompokkan menjadi tiga kelompok industri yaitu kelompok industri hulu, kelompok industri antara dan kelompok industi hilir. Kelompok industri hulu meliputi bokar (bahan olah karet), lump mangkok, dan kayu karet. Kelompok industri antara (setengah jadi) meliputi crumb rubber (karet remah), sheet/RSS, latek pekat, thin pole crepe, dan brown crepe. Adapun kelompok Industri hilir karet adalah industri yang menghasilkan produk akhir yang siap digunakan oleh industri pengguna meliputi ban dan produk terkait serta ban dalam kenderaan, barang jadi karet untuk keperluan industri, barang karet untuk kemiliteran, alas kaki dan komponennya, barang jadi karet untuk penggunaan umum, alat kesehatan dan laboratorium, dan lain-lain (Peraturan Menteri Perindustrian RI Nomor 112/M-IND/PER/10/2009).

Kebijakan industri nasional tahun 2015 - 2019 sebagaimana tertuang dalam Peraturan Presiden RI Nomor 2 tahun 2018 mengimanatkan bahwa kebijakan pengembangan industri nasional difokuskan kepada : (1) Peningkatan nilai tambah sumber daya alam pada industri hulu berbasis agro, mineral, serta migas dan batubara dalam rangka pendalaman struktur industri melalui penguatan rantai nilai industri dan pembangunan industri hulu yang diintegrasikan dengan industri antara dan industri hilirnya; (2) Peningkatan kapabilitas industri melalui peningkatan kompetensi sumber 
Tabel 2. Deskripsi Produk Karet

\begin{tabular}{|c|c|c|}
\hline No & Produk karet & Deskripsi \\
\hline 1 & HS4008 & $\begin{array}{l}\text { Plat, lembaran, strip, batang dan berbagai bentuk profil dari karet yang } \\
\text { divulkanisir. }\end{array}$ \\
\hline 2 & HS4009 & $\begin{array}{l}\text { Tabung, pipa, selang dari karet yang divulkanisir, dengan atau tanpa } \\
\text { perlengkapan seperti gabung, siku, atau penyambung jalur pipa (joints, elbows, } \\
\text { flanges). }\end{array}$ \\
\hline 3 & HS4010 & Conveyor belts atau Transmission Belts dari karet yang divulkanisir. \\
\hline 4 & HS4014 & $\begin{array}{l}\text { alat kontrasepsi wanita dan pria, dot bayi, pentil dot, tas es } \\
\text { dan berbagai peralatan kesehatan dari karet. }\end{array}$ \\
\hline 5 & HS4015 & $\begin{array}{l}\text { peralatan bedah dari karet, celemek karet, label dari karet, } \\
\text { sarung tangan, sarung tangan industri, pakaian selam dan } \\
\text { asesorisnya dan lainnya. }\end{array}$ \\
\hline 6 & HS4016 & $\begin{array}{l}\text { pelapis dalam pakaian, ubin lantai/dinding, penghapus, } \\
\text { penahan dermaga atau kapal, gasket dan cincin untuk } \\
\text { elektornik/kenderaan bermotor, bantal rel atau jembatan, } \\
\text { gelang karet, roler, tudung isolator listrik, penutup karet. } \\
\text { dan tali pengaman otomotif }\end{array}$ \\
\hline
\end{tabular}

Sumber : Cybex Exim, 2020

Daya manusia dan penguasaan teknologi; dan (3) Pembangunan industri di seluruh wilayah Indonesia melalui pembangunan wilayah pusat pertumbuhan industri (WPPI), kawasan peruntukan industri (KPI), kawasan industri, dan sentra industri kecil dan industri menengah (sentra IKM). Khusus pengembangan dan hilirisasi industri produk karet mendorong peningkatan konsumsi karet alam domestik (latex dan karet remah) oleh pendirian industri baru tahun 2017 - 2019 berupa benang karet, sarung tangan karet, dockfender, retread ban pesawat terbang dan ban kenderaan sebagaimana (Lampiran Perpres RI Nomor 2 tahun 2018). Kebijakan pengembangan industri karet tersebut (bersama sama dengan sektor lainnya) diperkuat dengan kerjasama ekonomi dengan negara lain dalam bentuk bilateral dan regional.

Potensi pasar produk karet di pasar dunia pada tahun 2016 mencapai sebesar USD 162,66 miliar, sedangkan realisasi ekspor produk karet dunia masih sebesar USD 123.640 miliar (International Trade Centre, 2018). Keadaan ini sangat memungkinkan Indonesia mengembangkan industri karet dilihat dari sisi permintaan. Indonesia berada pada peringkat 9 eksportir karet alam dan barang/produk karet di bawah Cina, Jerman, USA, Thailand, Jepang, Korsel, Perancis, dan Malaysia, dengan nilai ekspor (2016) sebesar USD 5,66 miliar, dimana USD 3,54 miliar merupakan ekspor produk hulu berupa TSR, RSS, latex, brown crepe dan karet konvensional lainnya, dan USD 2,06 miliar berupa ekspor berbagai produk karet. Berbagai jenis produk karet dideskripsikan sebagaimana Tabel 2. Pengembangan produk karet untuk pasar domestik masih memungkinkan melalui upaya substitusi impor khususnya untuk produk-produk yang bahan bakunya tersedia di dalam negeri, antara lain barang karet untuk konstruksi (fenders, bearings, conveyor belts), farmasi dan kesehatan (sarung tangan, dot/empeng, kondom), serta transportasi (ban off road, ban pesawat terbang, ban pejal), serta ekspansi pasar untuk produk karet potensial maupun pengembangan produk baru.

Tabel 3. Ekspor Produk Karet, Nilai dan Pangsa Asal Indonesia ke Negara ASEAN5 Periode 2005 - 2018

\begin{tabular}{|c|c|c|c|c|c|c|c|c|}
\hline \multirow{2}{*}{$\begin{array}{l}\text { Tujuan } \\
\text { ekspor }\end{array}$} & \multicolumn{6}{|c|}{ Jenis produk karet dengan kode HS: } & \multirow{2}{*}{$\begin{array}{l}\text { Ekspor rata-rata } \\
\text { (US\$juta) }\end{array}$} & \multirow{2}{*}{$\begin{array}{c}\text { Pangsa ekspor } \\
(\%)\end{array}$} \\
\hline & 4008 & 4009 & 4010 & 4014 & 4015 & 4016 & & \\
\hline Malaysia & $\checkmark$ & $\checkmark$ & $\checkmark$ & & $\checkmark$ & $\checkmark$ & 10,011 & 15 \\
\hline Singapore & $\checkmark$ & $\checkmark$ & $\checkmark$ & $\checkmark$ & $\checkmark$ & $\checkmark$ & 35,006 & 51 \\
\hline Thailand & $\checkmark$ & $\checkmark$ & $\checkmark$ & & & $\checkmark$ & 11,828 & 17 \\
\hline Filipina & & $\checkmark$ & $\checkmark$ & & & $\checkmark$ & 3,907 & 6 \\
\hline Vietnam & $\checkmark$ & $\checkmark$ & $\checkmark$ & & $\checkmark$ & $\checkmark$ & 7,852 & 11 \\
\hline Ekspor ke & & & & & & & & \\
\hline ASEAN5 & & & & & & & 68,605 & 16 \\
\hline
\end{tabular}

Sumber : Data penelitian, diolah 2020

Dalam periode tahun 2005 - 2018, Indonesia melakukan ekspor berbagai jenis produk karet khususnya kode HS 4008, 4009, 4010, 4014, 4015 dan 4016 ke berbagai negara rata-rata sebesar US\$ 431,403 juta per tahun. Khusus tujuan ekspor di ASEAN5 (Malaysia, Singapore, Thailand, Filipina, Vietnam) mencapai rata-rata US\$ 68,605 juta per tahun atau 16 persen dari total ekspor produk karet Indonesia sebagaimana Tabel 3. Indonesia melakukan ekspor 
produk karet dengan jenis cukup lengkap ke Singapore, namun sangat sedikit (atau tidak melakukan ekskpor) untuk jenis produk karet kode HS4014 ke empat negara ASEAN5 lainnya. Begitu juga hampir tidak ada ekspor produk karet kode HS4015 ke pasar Thailand dan Filipina. Fakta ini sangat mungkin terkait dengan berkembangnya industri produk karet sejenis di beberapa negara ASEAN5 tersebut serta semakin ketatnya kompetisi pasar dengan negara pengekspor besar dari Asia Timur (Cina, Jepang, Korea Selatan, Taiwan).

\section{Analisis RCA dan pangsa pasar produk karet Indonesia di negara ASEAN5}

Perdagangan internasional yang tercermin dari kegiatan ekspor dan impor suatu negara menjadi salah satu komponen dalam pembentukan PDB (Produk Domestik Produk) dari sisi pengeluaran suatu negara. Perdagangan internasional merupakan aktifitas yang dapat dilihat sebagai hubungan yang saling menguntungkan, dimana semua negara menjadi lebih baik dengan perdagangan internasional daripada membatasi perdagangan (Lairson and Skidmore, 2017).

Liberalisasi perdagangan mensyaratkan bahwa negara yang memiliki keunggulan kompetitif adalah negara dengan harga produk yang kompetitif. Keunggulan komparatif berasal dari keunggulan statik akibat adanya faktor bawaan (endowment factor) yang melimpah atau keunggulan pembelajaran (learning advantage). Kedua keunggulan tersebut akan menentukan daya saing. Perdagangan melalui pengembangan ekspor meningkatkan perekonomian negara sehingga sangat perlu memperhatikan daya saing produk yang diperdagangkan.

Dalam perdagangan internasional, daya saing diartikan sebagai kemampuan suatu komoditas dari suatu negara untuk dapat memasuki serta bertahan di pasar internasional. Daya saing adalah produktifitas yang merupakan bagian dari output yang dihasilkan oleh tenaga kerja, kapital, dan sumber daya alam di suatu negara. Suatu negara akan memperoleh keunggulan dalam daya saing jika perusahaan kompetitif dan mampu meningkatkan kemampuannya serta melakukan inovasi dalam industri perdagangan (Porter,1994).

Pertumbuhan daya saing komoditas ekspor suatu negara dapat mengalami fluktuasi. Hal ini disebabkan oleh banyak faktor, seperti adanya perubahan pangsa pasar komoditas terhadap total ekspor dan perubahan pangsa pasar komoditas dunia terhadap total ekspor dunia. Selain itu, fluktuasi juga disebabkan oleh perubahan pangsa pasar ekspor dari negara eksportir lainnya yang menjadi pesaing (Kusuma, 2015). Daya saing suatu negara juga dapat tergantung pada perubahan dari perilaku permintaan, tingkat kompetisi, dan kemampuan industri di suatu negara, oleh karena itu daya saing bersifat dinamis dan berfluktuasi antar waktu.

Aktifitas perdagangan melalui pengembangan ekspor dapat meningkatkan perekonomian negara sehingga sangat perlu memperhatikan daya saing produk yang diperdagangkan sebagaimana Lairson dan Skidmore (2017). Kusuma (2015) menyatakan daya saing produk ekspor suatu negara dapat mengalami fluktuasi yang disebabkan oleh banyak faktor seperti ditunjukkan perubahan pangsa pasarnya. Daya saing produk juga tergantung pada perubahan dari perilaku permintaan, tingkat kompetisi, dan produktivitas industri suatu negara.

Tabel 4. Indeks RCA dan Pangsa Produk Karet Indonesia di Negara ASEAN 5

\begin{tabular}{lccccccccc}
\hline \multirow{2}{*}{ Negara } & \multicolumn{7}{c}{ Tahun } \\
\cline { 2 - 10 } & 2010 & 2011 & 2012 & 2013 & 2014 & 2015 & 2016 & 2017 & 2018 \\
\hline Malaysia: & & & & & & & & & \\
RCA & 0.52 & 0.40 & 0.68 & 0.58 & 0.41 & 0.44 & 0.49 & 0.56 & 0.52 \\
Pangsa (\%) & 2.89 & 2.43 & 3.49 & 2.51 & 1.68 & 1.98 & 2.06 & 2.55 & 2.40 \\
\hline Singapore & 1.83 & 1.38 & 0.99 & 1.12 & 0.92 & 0.93 & 1.13 & 1.10 & 1.15 \\
RCA & 9.95 & 7.24 & 5.27 & 5.59 & 4.64 & 4.60 & 5.43 & 5.07 & 4.74 \\
Pangsa (\%) & & & & & & & & & \\
Thailand & 0.39 & 0.51 & 0.52 & 0.48 & 0.52 & 0.48 & 0.55 & 0.63 & 0.64 \\
RCA & 1.22 & 1.63 & 1.71 & 1.54 & 1.65 & 1.55 & 1.80 & 2.09 & 2.07 \\
Pangsa (\%) & & & & & & & & & \\
Filipina & 0.89 & 0.68 & 0.76 & 0.85 & 0.77 & 0.65 & 0.43 & 0.43 & 0.31 \\
RCA & 3.75 & 2.70 & 3.39 & 3.85 & 3.61 & 2.87 & 2.33 & 2.87 & 1.82 \\
Pangsa (\%) & & & & & & & & & \\
\hline Vietnam & 1.15 & 1.78 & 1.04 & 1.28 & 0.81 & 0.85 & 0.54 & 0.31 & 0.35 \\
RCA & 2.58 & 3.75 & 2.05 & 2.30 & 1.36 & 1.40 & 0.92 & 0.53 & 0.72 \\
Pangsa (\%) & & & & & & & &
\end{tabular}

Sumber : Data penelitian, diolah 2020

Mengukur kinerja ekspor produk tertentu suatu negara menggunakan RCA (Revalead Comparative Advantage) adalah mengevaluasi peranan ekspor produk tersebut di dalam ekspor total suatu negara dibandingkan dengan pangsa produk tersebut dalam perdagangan dunia sebagaimana Basri dan Munandar (2010). Konsep RCA 
dalam kontek ekspor menunjukkan keunggulan komparatif yang dimiliki oleh suatu negara. Variabel yang diukur adalah kinerja ekspor suatu produk terhadap total ekspor suatu wilayah yang kemudian dibandingkan dengan pangsa nilai produk dalam perdagangan dunia sebagaimana Tarman et al. (2011). Keunggulan komparatif merupakan daya saing suatu komoditas atau produk ekspor dari suatu negara terhadap ekspor sejenis negara lainnya.

Metode RCA (Revalead Comparative Advantage) merupakan metode yang dapat digunakan untuk mengukur keunggulan komparatif (comparative adventage) suatu produk negara di pasar dunia. Apabila nilai RCA lebih dari satu (RCA > 1) berarti produk tersebut memiliki daya saing yang kuat di pasar dunia. Semakin tinggi nilai RCA, maka semakin besar pula daya saing komoditas negara tersebut di pasar dunia.

Hasil analisis pada Tabel 4 dengan menggunakan indeks RCA (Revalead Comparative Advantage) selama periode 2010 sampai 2018, daya saing produk karet Indonesia di pasar negara ASEAN5 memiliki keunggulan komparatif yang cukup bervariasi. Produk karet Indonesia memiliki nilai daya saing relatif kuat $(\mathrm{RCA}>1)$ di pasar Singapore, namun daya saing menjadi lemah $(\mathrm{RCA}<1)$ pada pasar negara ASEAN5 lainnya seperti Malaysia, Thailand, Filipina dan Vietnam.

Daya saing produk karet Indonesia dalam periode 2010 sampai 2018 di negara ASEAN5 mengalami fluktuatif seperti keadaan menaik secara perlahan, cenderung stabil sampai menurun relatif besar. Daya saing produk karet Indonesia hanya menaik perkahan di pasar Thailand, sedangkan di pasar Malaysia cenderung stabil. Selebihnya, daya saing produk karet Indonesia mengalami penurunan cukup besar di pasar Singapore, Filipina dan Vietnam. Pada umumnya perubahan daya saing tersebut paralel dengan perubahan pangsa permintaan impor produk karet Indonesia di negara ASEAN5. Pelemahan daya saing produk karet Indonesia kemungkinan terkait dengan perkembangan industri sejenis di negara pengimpor dan semakin ketatnya persaingan produk karet dari kompetitor besar seperti Cina, Jepang dan Korea Selatan. Industri negara pesaing tersebut berkembang dengan skala relatif lebih besar dan memiliki keunggulan dalam desain produk, teknologi, harga, dan distribusi di negara pengimpor serta kulitas produk yang diperdagangkan.

\section{Posisi dan Potensi Pengembangan Pasar Produk Karet Indonesia di ASEAN5}

Posisi dan potensi pengembangan pasar produk karet Indonesia di negara ASEAN menggunakan analisis Export Product Dynamic (EPD) sebagaimana Tabel 5. Analisis ini mengukur posisi pasar dari komoditas suatu negara untuk tujuan pasar tertentu. Metode ini juga dapat menunjukkan dinamis atau tidaknya kinerja masing-masing komoditas. Analisis EPD dapat menunjukkan posisi daya saing suatu komoditas yang terbagi menjadi empat posisi yaitu Rising star, Falling star, Lost opportunity, dan Retreat. Hasil analisis EPD menunjukkan posisi pasar komoditas lada di masing-masing pasar yang diteliti cukup bervariasi. Ada yang berada pada posisi Rising star, Lost opportunity, Falling star maupun Retreat.

Permintaan impor produk karet Indonesia berada pada posisi Rising star di pasar Thailand, sedangkan di pasar Filipina permintaan impor produk karet Indonesia berada pada posisi Falling star. Ini berarti bahwa permintaan impor produk karet Indonesia ke pasar negara tersebut mengalami kehilangan kesempatan untuk meningkatkan pangsa pasar ekspor. Di pasar Malaysia, Singapore dan Vietnam, permintaan impor produk karet Indonesia berada pada posisi Retreat. Ini berarti produk karet Indonesia kehilangan kesempatan untuk meningkatkan pangsa pasar ekspor sekaligus pangsa pasar produk di pasar ke tiga negara tersebut.

Klusterisasi potensi potensi pengembangan pasar produk karet Indonesia selanjutnya menggunakan analisis RCA dan EPD di pasar negara ASEAN5. Metode yang digunakan adalah metode $x$-model potential export products, yaitu metode yang mempertimbangkan nilai daya saing yang diperoleh dari hasil analisis RCA dan posisi pasar yang diperoleh dari hasil analisis EPD. Analisis metode $x$-model potential export products lebih komprehensif karena mempertimbangkan daya saing produk karet Indonesia dari sisi indeks RCA dan posisi pasar (EPD).

Tabel 5. Hasil Analisis EPD Produk Karet Indonesia di Negara ASEAN5

\begin{tabular}{lccc}
\hline \multicolumn{1}{c}{ Negara } & Pertumbuhan Pangsa & Pertumbuhan Pangsa & \multirow{2}{*}{ Posisi Pasar } \\
& Pasar Ekspor $(\%)$ & Pasar Produk $(\%)$ & Retreat \\
Malaysia & -0.05 & -0.11 & Retreat \\
Singapore & -0.58 & -0.15 & Rising star \\
Thailand & 0.09 & 0.01 & Falling star \\
Filipina & -0.21 & 0.19 & Retreat \\
Vietnam & -0.21 & -0.02 & \\
\hline
\end{tabular}

Sumber : Data penelitian, diolah (2020) 
Tabel 6. Hasil Analisis X-Model Produk Karet Indonesia di Negara ASEAN 5

\begin{tabular}{lccc}
\hline Negara & RCA & EPD & Potensi Pengembangan Pasar \\
\hline Malaysia & 0.51 & Retreat & Tidak potensial \\
Singapore & 1.17 & Retreat & Kurang potensial \\
Thailand & 0.53 & Rising star & Potensial \\
Filipina & 0.64 & Falling star & Kurang potensial \\
Vietnam & 0.90 & Retreat & Tidak potensial \\
\hline
\end{tabular}

Sumber : Data penelitian, diolah (2020)

Hasil analisis pada Tabel 6 menunjukkan permintaan impor produk karet Indonesia memiliki potensi pengembangan pasar potensial di pasar Thailand. Hal ini karena produk karet Indonesia memiliki daya saing relatif lemah (RCA < 1) tetapi berada pada posisi pasar Rising star. Potensi pengembangan pasar produk karet Indonesia di Singapore dan Filipina pada posisi klasterisasi kurang potensial. Namun demikian daya saing produk karet Indonesia di pasar Singapore relatif kuat (RCA > 1) dan posisi pasar di pasar Filipina pada posisi Falling star. Di pasar Malaysia dan Vietnam, produk karet Indonesia memiliki potensi pengembangan pasar yang tidak potensial.

\section{KESIMPULAN}

1. Daya saing produk karet (kode HS 4008, 4009, 4010, 4014, 4015, 4016) Indonesia di pasar negara ASEAN5 memiliki keunggulan komparatif yang cukup bervariasi. Produk karet Indonesia memiliki nilai daya saing relatif kuat (RCA > 1) di pasar Singapore, namun daya saing menjadi lemah (RCA < 1) pada pasar negara ASEAN5 lainnya seperti Malaysia, Thailand, Filipina dan Vietnam. Produk karet Indonesia bersaing ketat dengan perkembangan industri sejenis di negara pengimpor dan semakin ketatnya persaingan produk karet dari pesaing besar seperti Cina, Jepang dan Korea Selatan.

2. Permintaan impor produk karet Indonesia berada pada posisi Rising star di pasar Thailand, sedangkan di pasar Filipina permintaan impor produk karet Indonesia berada pada posisi Falling star. Ini berarti bahwa permintaan impor produk karet Indonesia ke Thailand sedang tumbuh berkembang secara perlahan dan di pasar Filipina mengalami kehilangan kesempatan untuk meningkatkan pangsa pasar ekspor. Di pasar Malaysia, Singapore dan Vietnam, permintaan impor produk karet Indonesia berada pada posisi kehilangan kesempatan untuk meningkatkan pangsa pasar ekspor sekaligus pangsa pasar produk di pasar ke tiga negara tersebut (posisi pasar Retreat).

3. Klasterisasi potensi pasar menunjukkan permintaan impor produk karet Indonesia memiliki potensi pengembangan pasar potensial di pasar Thailand, walaupun memiliki daya saing relatif lemah $(\mathrm{RCA}<1)$ tetapi berada pada posisi pasar Rising star. Potensi pengembangan pasar produk karet Indonesia di Singapore dan Filipina pada posisi klasterisasi kurang potensial, namun memiliki daya saing di pasar Singapore relatif kuat (RCA > 1) dan posisi pasar di Filipina adalah Falling star. Produk karet Indonesia berhadapan dengan potensi pengembangan pasar yang tidak potensial di Malaysia dan Vietnam.

\section{DAFTAR PUSTAKA}

Basri, F. \& Munandar, H. (2010). Dasar-dasar Ekonomi Internasional: Pengenalan dan Aplikasi Metode Kuantitatif. Jakarta (ID) : Kencana.

Balassa, B. (1965). Trade Liberalisation and 'Revealed' Comparative Advantage. Manchester School of Economics and Social Studies, 33: 99-123.

Balassa, B. (1989). Comparative Advantage, Trade Policy and Economic Development. New York and London : Harvester Wheatsheaf.

Blagrave, P., \& Vesperoni, E. (2016). Spillover Implications of China's Slowdown for International Trade. IMF Spillover Notes No. 16/04, International Monetary

Fund. Available http://www.imf.org/external/pubs/cat/longres.aspx?sk=44292

Basri, M. F., M. S. Hapka., M. N. Jaafar., A. A. Muhamat. (2018). Determinants of the Price of Natural Rubber in Malaysia; International Journal of Business \& Management, 6(12): 50-54

Drysdale., P. D., Y. Huang., \& Kalirajan, K. (2000). China's Trade Efficiency: Measurement and Determinants, in P. Drysdale, Y. Zhang and L. Song (eds) APEC and Liberalisation of the Chinese economy, Canberra, Asia Pacific Press.

Dinda, S. (2017). Impact of the people's republic of China's slowdown on the global economy ADBI Working Paper Series, No.784, Asian Development Bank Institute. 
Esterhuizen, D. (2006). Analysing Competitiveness in the Agribusiness Sector: Methodological and Analytical Framework. Petroria: University of Petroria.

Hasibuan, A.M,. N. Rita., dan Agus, W. (2012). Analisis kinerja dan daya saing perdagangan biji kakao dan produk kakao olahan indonesia di pasar internasional. Buletin Risti. 3(1): 57-70.

International Trade Centre. (2018). Export potential map. Retrieved, December 8, 2018, from http://www.itc.org/

Krugman, P. R. and Obstfeld, M. (2003). International Economics Theory and Policy. New York (USA) : Addison Wesley Longman, Inc.

Kementerian Perdagangan. (2013). Kajian Potensi Pengembangan Ekspor ke Pasar Non Tradisional. Jakarta (ID): Pusat Kebijakan Perdagangan Luar Negeri BP2KP.

Kusuma, N. A. (2015). Analisis Daya Saing dan Perdagangan Produk Ekspor Kelapa Sawit Indonesia di Pasar Internasional. (Thesis Repository). Bogor Agricultural University, Indonesia.

Lairson, T. D. \& Skidmore, D. (2017). International Political Economy: The Struggle for Power and Wealth. New York (USA): Routledge.

Oktora, S. I, dan A. M. Firdani. (2019). Natural Rubber Economics between China and Southeast Asia: The Impact of China's Economic Slowdown. Journal of Asian Finance, Economics and Business, 6 (2): 55-62

Porter, M. E. (1994). Keunggulan Bersaing. Jakarta (ID): Binarupa Aksara

Ramli, N., S. Abu Hasan., T. Sarmidi., F. S. Fathin., A. H. Azam. (2019). Modelling the Volatility of Rubber Prices in ASEAN-3. International Journal of Business and Society, 20(1):1-18

Sattayawaksakul, D and Seung, Y.C. (2016) A Comparative Analysis of Export Competition in Natural Rubber among the Leading Exporters in Southeast Asia. The $4^{\text {th }}$ International Scholars Conference (4ISC). PUBLISHED: 2016-11-01. DOI : https://doi.org/10.35974/isc.v4i1.1751

Tarman., K, Dewi., W. Hari., F. Umar., M. Naufa., \& Bambang, S.W. (2011). Kajian Kebijakan Pengembangan Diversifikasi Pasar dan Produk Ekspor. Laporan Akhir Kajian Kementerian Perdagangan Republik Indonesia. Retrieved Maret 26 2020, from: www.kemendag.go.id/files/pdf/2014/01/06/Full-Report-

United Nation Comtrade. (2020). Comtrade Database Statistic. Available online: http://www.comtrade.org/

Zainuddin, (2019b). Kekuatan Pasar dan Dampak Pelemahan Permintaan, Tarif Impor, Investasi Terhadap Perdagangan Karet Alam dan Produk Karet Indonesia. Dissertation Repository. Bogor Agricultural University, Indonesia. http://repository.ipb.ac.id/handle

Zainuddin,. B. M. Sinaga., S. Hartoyo., \& Erwidodo. (2019a). Dampak Penurunan Tarif Impor, Investasi dan Relokasi Industri Ban Terhadap Perdagangan Karet Alam dan Ban Indonesia di Pasar Dunia. Buletin Ilmiah Litbang Perdagangan, 13(1), 71-98. 